\title{
Chronic Degenerative Diseases Before and After the COVID-19 Pandemic in Mexico
}

\author{
Melchor Alpízar-Salazar*, Melchor Rodrigo Alpízar-Sánchez, Jesús Manuel De Aldecoa-Castillo, \\ Alfredo Romero-Cervantes, María Fernanda Alpízar and Tamara Daniela Frydman \\ Specialized Centre for Diabetes, Obesity and Prevention of Cardiovascular Diseases, Mexico
}

*Corresponding author: Melchor Alpízar-Salazar, MD, PhD, FACE, Specialized Centre for Diabetes, Obesity and Prevention of

Cardiovascular Diseases, Mexico City 11650, Mexico

\begin{tabular}{|c|c|}
\hline ARTICLE INFO & ABSTRACT \\
\hline $\begin{array}{l}\text { Received: 幽 May 28, } 2020 \\
\text { Published: 幽 June 15, } 2020\end{array}$ & $\begin{array}{l}\text { Citation: Alpízar-Salazar M, Melchor R Alpízar-Sánchez, Jesús Manuel De Aldecoa-Cas- } \\
\text { tillo, Alfredo Romero-Cervantes, María Fernanda A, et al., Chronic Degenerative Dis- } \\
\text { eases Before and After the COVID-19 Pandemic in Mexico. Biomed J Sci \& Tech Res } \\
\text { 28(2)-2020. BJSTR. MS.ID.004627. }\end{array}$ \\
\hline
\end{tabular}

\section{Mini Review}

Lifestyle choices are of the utmost importance when discussing disease prevention and treatment. Time and again, doctors and scientists have proven that pre-existing conditions are almost always a risk factor for disease severity in both non-communicable and transmitted diseases as well as acute and chronic. Since 2002, the World Health Organization (WHO) has shed light on one of the main concerns that amount to the development of chronic illness, obesity. This was approached through a document titled "Diet, Nutrition and the Prevention of Chronic Diseases", that discussed in depth the way nutritional habits and lifestyle choices are deeply related to the growing epidemic of chronic diseases. To this effect, in the year 2014 the World Health Organization (WHO) predicted that chronic degenerative diseases would be the primary health issue by 2020 [1].

\section{Metabolic Diseases in Mexico}

5-15 years ago, in Mexico, Diabetes Mellitus (DM) was the primary cause of death for $33 \%$ of women and $26 \%$ of men. The WHO said that more than $50 \%$ of deaths worldwide were due to chronic illness and that, this percentage would increase by $17 \%$ in the next 10 years, this has already come true [2]. From a sociocultural perspective, there are inherent aspects of these factors that cause significant problems. The "normal" diet in the Mexican population is taught from prior generations and has several economic and political factors that surround it. In this manner, nutritional habits are a reflection of our surroundings. Mexico has a cultural and social tendency towards high caloric diets, with simple carbohydrates and saturated fats, which has led to a genetic predisposition for degenerative chronic illness in the population, based on malnutrition. This includes the whole spectrum, from undernutrition to overweight and obesity [3]. According to the National Health and Nutrition Survey (ENSANUT) of 2018, Mexico has the following prevalence for the diseases associated with Metabolic Syndrome:

a) Diabetes Mellitus: $10.3 \%, 8.6$ million people, in a population of 20 years or older.

b) Systemic Arterial Hypertension: $18.4 \% 15.2$ million people, in a population of 20 years or older. $26 . \%$ in a population of 70 years or older.

c) Dyslipidemia: $19.5 \%$, in a population of 20 years or older.

d) Overweight: $8.2 \%$ in a population of 0-4 years old. 18.1 $\%$ in a population of 5-11 years old. $23.8 \%$ in a population of 12-19 years old. $39.1 \%$ in a population of 20 years or older.

e) Obesity: $17.5 \%$ in a population of 5-11 years old. $14.6 \%$ in a population of 12-19 years old. $36.1 \%$ in a population of 20 years or older [4].

For overweight and obesity, the parameter is Body Mass Index (BMI), however, current research has observed that Fat Mass Index (FMI) is a more precise indicator to classify weight with. With this index, research shows that the Mexican pediatric population (ages 6-12) tends to develop adipose hypertrophy (measured with FMI), 
this is a way to detect those cases with a normal weight obesity. These children are at risk for chronic degenerative diseases in adulthood [5]. These statistics come with economic consequences as well, recent estimations calculate that approximately $73-87 \%$ of the planned health budget is going towards these health issues only in public health institutions [6].

\section{Government Efforts}

In the last decade, the Mexican government has made several efforts to tackle the Diabetes Mellitus epidemic. The first, was the publication of an official policy (NOM-015-SSA2-2010) titled "For the Prevention, Treatment, and Control of Diabetes Mellitus". This policy recognized the need for attention to this illness and its consequences as well as the problems that Mexico faces that had limited the efficacy of institutional programs with this same purpose. Among others, the insufficient supply of medications, inadequate and/or obsolete equipment in health units, poor access to laboratory testing, deficiencies in the system for referring patients, limitations in supporting services such as psychological and nutritional guidance, no physical activity promotion, and scarce supervision of services for therapeutic adherence achievement. The general goal of implementing this policy was to ultimately consolidate a legal background for preventing, treating, and controlling the disease [7]. However, the general perspective was disheartening when in 2012 the ENSANUT survey identified a significant increase in overweight and obesity in all age groups and both rural and urban communities, making these factors along with DM, a national health priority [8].

On October 31st of 2013, the Mexican government presented the National Strategy for the Prevention and Control of Overweight, Obesity, and Diabetes. This strategy was based on four axes: that health must be present on all public policies, that medical attention should be based on social determinants and cover health promotion and assistance, that efforts in all sectors should be privileged, and that measuring impact is essential for proper function. Its main goal was to improve well-being for the Mexican population and contribute to sustainability in national development by contributing to decrease these health issues [9]. The results of this strategy were measured in 2016 using two instruments:

a) The first was an Indicators System developed by the Mexican Institute for Competitiveness A.C. and the Aspen Institute Mexico.

b) The second was the Final Report on the National Health and Nutrition Survey of 2016. This survey identified that overweight and obesity in Mexico was on the rise, more common among women of all age groups. This shed light on the need to focus future strategies on women $[10,11]$.

\section{COVID-19 and Chronic Degenerative Diseases}

Persistent inflammation is a high-risk factor for chronic degenerative diseases. Obesity and diabetes are key triggers for said inflammation, by promoting the constant release of proinflammatory cytokines such as IL-1, IL-6 and TNF- $\alpha$ [12]. With obesity, there is also a decrease in the anti-inflammatory stimuli like adiponectin, which in turn activates endothelial dysfunction by decreasing nitric oxide and elevated levels of reactive oxygen species [13]. COVID-19, an infectious disease caused by coronavirus infection, can originate -in some patients- a cytokine storm that involves pro-inflammatory cytokines and can lead to multi-organ failure [14]. One hypothesis is that this is brought on by postprandial glycemic spikes that increase immune system activation (through the hexosamine pathway that leads to interferon regulatory factor-5 increasing cytokine production) [15]. This profile has been observed increasingly in critical patients. Studies from several countries have found that about $80 \%$ of critical patients in need of hospital care have at least one underlying chronic condition, of which the most common were overweight/obesity, hypertension, chronic lung disease, diabetes, and cardiovascular disease [1618]. Furthermore, findings suggest that COVID-19 infection can cause direct damage to pancreatic $\beta$-cells by binding to pancreatic angiotensin-converting enzyme 2 (ACE2) receptors and thereby reducing insulin secretion, leading to hyperglycemia [15].

In short, the link between fatal COVID-19 cases and cardiometabolic comorbidities has been made, which implies a serious challenge in this pandemic, especially for a country like Mexico with the prevalence for this disease being so high [19].

\section{What's next?}

Modulating the hyperinflammatory response to COVID-19 is a priority now, but the lesson we take from this experience should be permanent. Preventive health intervention is key when dealing with chronic degenerative diseases such as obesity, diabetes mellitus, and hypertension. In the case of diabetes, perhaps low glycemic diets could result beneficial for COVID-19 infected patients given the immune response exacerbated by hyperglycemia. Mexico is a country where unfortunately these diseases have high prevalence and incidence rates, and governmental measures have been found to be insufficient to tackle this problem. So far, government efforts have been medically focused, and while this is indispensable, may be a lack of an in depth social and psychological approach is what has been missing to achieve the wanted results. Workshops, classes, group dynamics, and talks might be crucial to make a strong connection with communities and get them to commit to their healthcare as well, leading to changes in their lifestyle. This issue is the responsibility of our whole community. This includes nonprofit organizations, businesses, health workers, and education 
campaigns that can create awareness of the importance of healthy habits and the consequences of not implementing them, not only for the chronic diseases they lead to but also the way they affect the body's response to infectious diseases as well.

\section{Disclosure statement}

The authors declare that there are no potential conflicts of interest.

\section{References}

1. (2003) Who J, Consultation FE Diet, nutrition and the prevention of chronic diseases. World Health Organ Tech Rep Ser 916: i-viii.

2. Erazo LR, Becerra Gálvez AL (2014) Medicina Conductual: Teoría y Práctica. Primera Ed. Ciudad De México: Qartuppi.

3. Ortega Carmona D, García Guzmán M (2018) Políticas Públicas de Combate a la Malnutrición en México. Análisis de la Cruzada Nacional Contra el Hambre y la Estrategia Nacional para la Prevención y Control del Sobrepeso, la Obesidad y la Diabetes. Universidad Nacional Autónoma de México.

4. (2019) Instituto Nacional de Salud Pública. Encuesta Nacional de Salud y Nutrición 2018. ENSANUT.

5. Alpízar M, Frydman TD, Reséndiz-Rojas J de J, Trejo-Rangel MA, De Aldecoa-Castillo JM (2020) Fat Mass Index (FMI) as a Trustworthy Overweight and Obesity Marker in Mexican Pediatric Population. Children 7 (3): 19.

6. Shamah-Levy T, Amaya-Castellanos MA, Cuevas-Nasu LD (2015) Obesidad: doble carga en México. Revista Digital Universitaria: 2-10.

7. (2010) Para la Prevención, Tratamiento y Control de la Diabetes Mellitus. Norma Oficial Mexicana NOM-015-SSA2-2010.

8. Romero-Martínez M, Shamah-Levy T, Franco-Núñez A, Villalpando $S$, Cuevas-Nasu L, et al. (2013) Encuesta Nacional de Salud y Nutrición 2012: diseño y cobertura. Salud Pública de México 55: S332-S340.

9. Secretaría de Salud (2013) Estrategia Nacional para la Prevención y el Control del Sobrepeso, la Obesidad y la Diabetes, IEPSA, México.

ISSN: $2574-1241$

DOI: $10.26717 /$ BJSTR.2020.28.004627

Melchor Alpízar-Salazar. Biomed J Sci \& Tech Res

This work is licensed under Creative Commons Attribution 4.0 License

Submission Link: https://biomedres.us/submit-manuscript.php
10. Ortega-Carmona D (2018) Políticas Públicas de Combate a la Malnutrición en México. Análisis de la Cruzada Nacional Contra el Hambre y la Estrategia Nacional Para la Prevención y Control del Sobrepeso, la Obesidad y la Diabetes; Tésis para Optar Por el Grado de Maestro en Gobierno y Asuntos Públicos. Universidad Nacional Autónoma de México.

11. Secretaría de Salud (2016) Encuesta Nacional de Salud y Nutrición de Medio Camino 2016, Informe Final de Resultados, 31 de octubre de 2016, México.

12. Pal R, Bhadada SK (2020) COVID.19 and non-communicable diseases. Postgrad Med J Epub.

13. Ellulu MS, Patimah I, Khaza H, Rahmat A, Abed Y (2017) Obesity and inflammation: the linking mechanism and the complications. Arch Med Sci 13: 851-863.

14. Schett G, Sticherling M, Neurath MF (2020) COVID-19: risk for cytokine targeting in chronic inflammatory diseases? Nat Rev Immunol 20(5): 271-272.

15. Cole SA, Laviada-Molina HA, Serres-Perales JM, Rodriguez-Ayala E, Bastarrachea RA (2020) The COVID-19 Pandemic during the Time of the Diabetes Pandemic: Likely Fraternal Twins? Pathogens 9(5): 389.

16. Garg S (2020) Hospitalization rates and characteristics of patients hospitalized with laboratory-confirmed coronavirus disease 2019-COVID-NET, 14 States, March 1-30, 2020. MMWR. Morbidity and Mortality Weekly Report 69 (15): 458-464.

17. Richardson S, Hirsch JS, Narasimhan M, Crawford JM, Mc Ginn T, et al. (2020) Presenting Characteristics, Comorbidities, and Outcomes Among 5700 Patients Hospitalized With COVID-19 in the New York City Area. JAMA 323(20):2052-2059.

18. Grasselli G, Zangrillo A, Zanella A, Antonelli M, Cabrini L, et al. (2020) Baseline characteristics and outcomes of 1591 patients infected with SARS-CoV-2 admitted to ICUs of the Lombardy Region, Italy. Jama 323(16): 1574-1581.

19. Bello-Chavolla OY, Bahena-Lopez JP, Antonio-Villa NE, Vargas-Vázquez A, González-Díaz A, et al. (2020) Predicting mortality attributable to SARSCoV-2: A mechanistic score relating obesity and diabetes to COVID-19 outcomes in Mexico. MedRxiv 52.

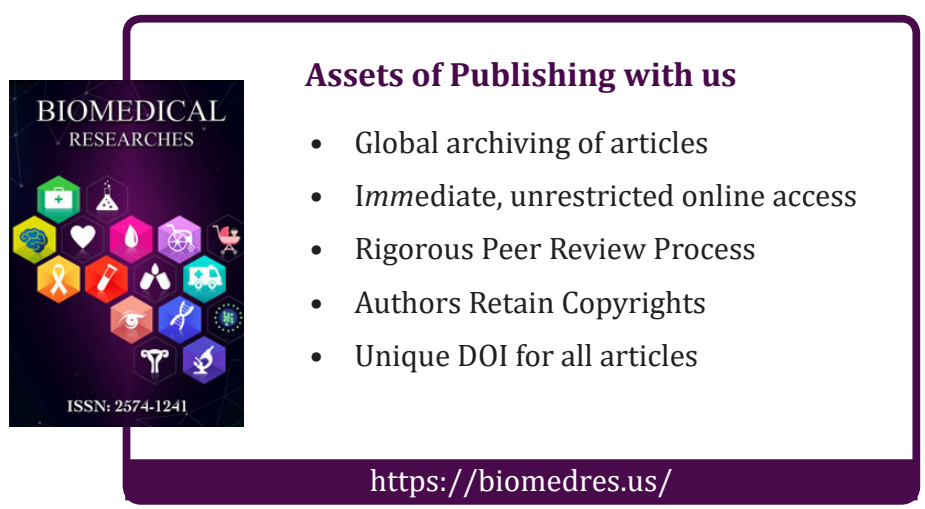

